\title{
Mating system of a population of Myracrodruon urundeuva F.F. \& M.F. Allemão using the fAFLP molecular marker
}

\author{
Miguel L.M. Freitas ${ }^{1}$, Alexandre M. Sebbenn ${ }^{2}$, Mario L.T. Moraes ${ }^{3}$ and Eliana G.M. Lemos ${ }^{1}$ \\ ${ }^{1}$ Universidade Estadual Paulista, Faculdade de Ciências Agrárias e Veterinárias, \\ Departamento de Tecnologia, Jaboticabal, SP, Brazil. \\ ${ }^{2}$ Instituto Florestal de São Paulo, Departamento de Conservação e Melhoramento Genético, \\ São Paulo, SP Brazil. \\ ${ }^{3}$ Universidade Estadual Paulista, Faculdade de Engenharia, Departamento de Fitotecnia, \\ Ilha Solteira, SP, Brazil.
}

\begin{abstract}
The mating system and genetic diversity were studied in a natural population of Myracrodruon urundeuva originating from 30 open-pollinated trees at the Paulo de Faria Ecological Station, SP, Brazil. The progenies were planted on the Teaching and Research Farm of the llha Solteira Engineering School, UNESP. Using the fAFLP molecular marker, eleven loci were selected to study the mating system. The mating system was analyzed using the multilocus mixed-mating model. The estimates of genetic divergence between pollen and ovule allele frequencies were significant for eight loci, suggesting nonrandom outcrossing. The estimates of the multilocus outcrossing rate revealed that $M$. urundeuva possesses a mating system with a predominance of outcrossing events $(\hat{\theta}=0.940 \pm$ $0.086)$. The estimates of coancestry among plants within progenies $(\hat{\theta}=0.185)$ was higher than that expected for half-sib progenies $(0.125)$ and the indirect estimate of the correlation of outcrossed paternity within progeny arrays $\left(\hat{r}_{p}\right)$ was 0.403 , suggesting that progenies have a high proportion of full-sibs. Result analysis suggests the need for the application of biometric models that take into account deviations from random outcrossing in the estimations of genetic parameters for quantitative traits and the need for retaining large sample sizes in order to preserve genetic variability.
\end{abstract}

Key words: Myracrodruon urundeuva, mating system, fAFLP, molecular marker, correlation of paternity.

Received: July 1, 2003; Accepted: April 1, 2004.

\section{Introduction}

The understanding of the mating system of a species is of fundamental importance for genetic improvement and conservation programs because it permits the outlining of strategies that optimize the sampling of genetic variability and the adoption of genetic-statistical models appropriate for the estimation of genetic parameters. Information about the mating system, diversity and genetic structure, as well as the spatial distribution of genotypes within populations, is important for the establishment of strategies aimed at the effective conservation of any species.

The mating system and the genetic structure of a species are directly related to its ecology and genetics (Loveless et al., 1998). A species can produce its descendants by different types of mating such as random outcrossing, correlated outcrossing, biparental inbreeding, self-fertilization, apomixes and their combinations. The mating system,

Send correspondence to Miguel Luiz Menezes Freitas. E-mail: mfreitas@fcav.unesp.br. together with the mechanism of pollen and seed dispersion, determines part of the genetic structure of populations (Hamrick and Loveless, 1986). Species resulting from outcrossing maintain most of their genetic variability distributed within populations, in contrast to predominantly selfed species in which most of the genetic variability is distributed between populations (Hamrick, 1983; Hamrick and Godt, 1989). Studies on the mating system of tropical tree species using genetic markers have shown that most species are allogamous or possess a mixed mating system with a predominance of allogamy (Murawski et al., 1990; Murawski, 1995).

The fAFLP (fluorescence Amplified Fragment Length Polymorphism) technique, developed by Vos et al. (1995), has been frequently utilized in genetic studies and offers practical advantages for DNA analysis since it generates a large number of polymorphic markers (Gaiotto et al., 1997), which is mainly due to resolution specificity, digestion sampling power with restriction enzymes and to the 
fast and practical detection of polymorphisms by means of PCR (Ferreira and Grattapaglia, 1998). Further advantages are the use of less DNA, and the possibility of wide genome studies (Scott et al. 2000).

The fAFLP marker aimed to utilize a robust mark which would yield a large number of loci. The species was evaluated for isoenzymatic and RAPD-type markers and microsatellite loci that have not been developed for this species. For this reason, the AFLP marker was selected. Although this is a dominant inheritance marker, it is more robust than RAPD markers and yields a large number of loci in simple gel (Ferreira and Grattapaglia, 1998).

The constant removal of native forest species and the exploitative cultivation of commercial species in monocultures have caused erosion in the forest diversity of different Brazilian ecosystems. Studies on native tree species have mainly been carried out since the end of the eighties, when research centers started to draw attention to the conservation of the genetic resources of these species. Among these species is Myracrodruon urundeuva F.F. \& M.F. Allemão which, due to its high economic value and its occurrence throughout most of Brazil, has suffered, year after year, a frequent reduction in population number and size as a result of the extinction of its habitat. M. urundeuva (Anacardiaceae) is found from Ceará to Paraná and throughout the Center-West region in the "Cerrado" areas or surrounding regions (Rizzini, 1971; Lorenzi, 1992). It also occurs in the "Chaco" formations of Paraguay and Argentina. However according to Rizzini (1971), Nogueira et al. (1982) and Santin and Leitão Filho (1991), Brazil is center for the origin of this species . Lorenzi (1992) described the species as a deciduous, heliophytic and selective xerophytic plant characteristic of dry and rocky soils, which occurs in dense groups in both open and very dry (scrubland), very humid and closed formations. It varies in size, with a height of up to $15 \mathrm{~m}$ and a diameter ranging from 15 to $30 \mathrm{~cm}$ as observed in the "Cerrado" and scrubland, and a height of up to $30 \mathrm{~m}$ and a diameter of $1 \mathrm{~m}$ for fertile soils in semi deciduous broad-leaf forests (Corrêa, 1926; Record and Hess, 1949; Rizzini, 1971; Santin and Leitão Filho, 1991). Its inflorescences are paniculate, terminal and axillary, and multifloral, measuring about $20 \mathrm{~cm}$ in length. Its flowers are attractive to insects and are mainly foraged by hymenopterans. The fruits, containing a single seed, are round drupes always accompanied by a persistent and wide chalice which helps in fruit dispersal (Santin and Leitão Filho, 1991). M. urundeuva is predominately dioecious, but monoecious trees can also be found (Carvalho, 1994). In dioecious species, all sibs are produced by outcrosses. But it may occur by biparental inbreeding, correlated mating and random mating. The pattern of mating can be measured by the correlated mating model (Ritland, 1989). Thus the objective of the present study was to determine the mating system of an M. urundeuva population, using the fAFLP molecular markers.

\section{Material and Methods}

\section{Sampling}

The mating system was studied in open-pollinated trees originating from a natural population of M. urundeuva at the Paulo de Faria Ecological Station, São Paulo State, Southeast of Brazil. The Ecological Station is located at $19^{\circ} 55^{\prime} \mathrm{S}, 49^{\circ} 31^{\prime} \mathrm{W}$, at an elevation of $650 \mathrm{~m}$, and with an area of 435.7 ha. This area is savannah woodland where $M$. urundeuva is common ( $>1$ individual per hectare), but the species appear only in a small section of the area (approximately 50 hectares). In the past, the population underwent some sort of anthropic intervention.

Nine plants per progeny were analyzed from 30 mother trees and the progenies were then planted on the Teaching and Research Farm of the Ilha Solteira Engineering School, UNESP, SP.

\section{DNA extraction}

DNA was extracted from leaf tissue of each sample according to Doyle and Doyle (1987), with the following modifications: Plant tissues $(0.1 \mathrm{~g})$ were macerated in liquid nitrogen, $750 \mu \mathrm{L}$ of CTAB extraction buffer $(1 \mathrm{M}$ Tris-HCl, $\mathrm{pH}$ 8.0, 1.4 M NaCl, 0.5 M EDTA, pH 8.0, 2\% $\mathrm{CTAB}$ and $0.2 \% \beta$-mercaptoethanol) was added, and the samples were heated to $60^{\circ} \mathrm{C}$ for 30 min under occasional shaking. The samples were cooled at room temperature for approximately $10 \mathrm{~min}$, and then $450 \mu \mathrm{L}$ chloroform/isoamyl alcohol (24:1) was added to each tube. The samples were shaken by inversion for $8 \mathrm{~min}$ and centrifuged at $2,000 \mathrm{x} \mathrm{g}$ for $10 \mathrm{~min}$ at $20^{\circ} \mathrm{C}$. The supernatants were collected and transferred to new tubes. A 2/3 volume (approximately $400 \mu \mathrm{L}$ ) of ice-cold isopropanol was added and the solutions were carefully mixed in order to precipitate the nucleic acids. Nucleic acids were recovered after centrifugation of the solution at $10,000 \mathrm{x}$ g for $10 \mathrm{~min}$ at $0{ }^{\circ} \mathrm{C}$. The pellet was then washed with $1.3 \mathrm{~mL}$ washing buffer $(76 \%$ $\mathrm{v} / \mathrm{v}$ ethanol, $10 \mathrm{mM}$ ammonium acetate) for $20 \mathrm{~min}$. Nucleic acids were centrifuged at $12,000 \mathrm{x}$ g for $10 \mathrm{~min}$, the supernatant was carefully discarded, and the pellet air dried at room temperature, and finally resuspended in $100 \mu \mathrm{L}$ TE (10 mM Tris-HCl, pH 7.4, 1 mM EDTA). RNase at a concentration of $10 \mu \mathrm{g} / \mathrm{mL}$ was added and the samples incubated for $30 \mathrm{~min}$ at $37^{\circ} \mathrm{C}$. The samples were then diluted in 2 volumes of distilled water, followed by the addition of 1 volume of $7.5 \mathrm{M}$ ammonium acetate, $\mathrm{pH} 7.7$, at a final concentration of $2.5 \mathrm{M}$, and 2.5 volumes of ice-cold ethanol, and the precipitated nucleic acids were carefully mixed. The samples were left to stand at $-20^{\circ} \mathrm{C}$ for $1 \mathrm{~h}$. Nucleic acids were centrifuged at $12,000 \mathrm{xg}$ for $10 \mathrm{~min}$ at $4{ }^{\circ} \mathrm{C}$, and the pellet was dried and resuspended in $20 \mu \mathrm{L}$ TE. Nucleic acid samples were quantified with a spectrophotometer by determining the absorbance at $260 \mathrm{~nm}$, according to Sambrook et al. (1989). 


\section{fAFLP}

The extracted DNA samples were submitted to digestion in a reaction mixture containing $500 \mathrm{ng}$ DNA, $2.5 \mathrm{U}$ MseI, 3.0 EcoRI and 1.25 $\mu \mathrm{L}$ Reactl buffer (Invitrogen). The reactions were incubated at $37^{\circ} \mathrm{C}$ for $24 \mathrm{~h}$, followed by incubation at $70{ }^{\circ} \mathrm{C}$ for $15 \mathrm{~min}$ to inactivate the restriction enzymes.

This step was followed by the ligation of adaptors to the digested DNA fragments. The ligation reactions consisted of $3.67 \mu \mathrm{L}$ of the digestion reaction, 1.5 U T4 DNA ligase, $1.0 \mu \mathrm{L}$ T4 ligase buffer $(1 \mathrm{U} / \mu \mathrm{L})$ and $0.66 \mu \mathrm{L}$ of each adaptor. The reactions were incubated at $20^{\circ} \mathrm{C}$ for $2 \mathrm{~h}$ and then $45 \mu \mathrm{L}$ TE was added. The fragments ligated to the adaptors were amplified by a PCR reaction, consisting of 4 $\mu \mathrm{L}$ ligated DNA, $1 \mu \mathrm{L}$ AFLP EcoRI/MseI primer and 15 $\mu \mathrm{L}$ AFLP Core Mix (Taq DNA polymerase, MgCl2, PCR buffer, dNTP - PE Applied Biosystems - Foster City, CA). The amplification program was: $72{ }^{\circ} \mathrm{C}$ for $2 \mathrm{~min}$, followed by 20 cycles at $94{ }^{\circ} \mathrm{C}$ for $20 \mathrm{~s}, 56^{\circ} \mathrm{C}$ for $30 \mathrm{~s}$ and $72{ }^{\circ} \mathrm{C}$ for $2 \mathrm{~min}$. After the pre-selective amplification, $10 \mu \mathrm{L}$ of each sample was loaded on a $1 \%$ agarose gel stained with ethidium bromide $(0.5 \mu \mathrm{g} / \mathrm{mL})$ to detect amplification. The remaining pre-selective amplification products $(10 \mu \mathrm{L})$ were diluted in $90 \mu \mathrm{L}$ TE 0.1 and submitted to the selective amplification consisting of $3.0 \mu \mathrm{L}$ of the pre-selective amplification product, $1.0 \mu \mathrm{L}$ of the MseI primer, $1.0 \mu \mathrm{L}$ of the EcoRI primer, and 15.0 $\mu \mathrm{L}$ AFLP Core Mix. The PCR consisted of the following steps: 1) one cycle at $94{ }^{\circ} \mathrm{C}$ for $2 \mathrm{~min}$; 2) one cycle at $94^{\circ} \mathrm{C}$ for $1 \mathrm{~min}, 66^{\circ} \mathrm{C}$ for $1 \mathrm{~min}$ and $72{ }^{\circ} \mathrm{C}$ for $2 \mathrm{~min} ; 3$ ) one cycle at $94{ }^{\circ} \mathrm{C}$ for $20 \mathrm{~s}, 65^{\circ} \mathrm{C}$ for $30 \mathrm{~s}$ and $72{ }^{\circ} \mathrm{C}$ for $2 \mathrm{~min}$, with the steps running up to the 10th one marked by a $1{ }^{\circ} \mathrm{C}$ decrease in the temperature of the intermediate cycle of the previous step until reaching a temperature of $58{ }^{\circ} \mathrm{C}$, with the remaining conditions kept constant. The eleventh step consisted of 20 cycles at $94{ }^{\circ} \mathrm{C}$ for $30 \mathrm{~s}, 56{ }^{\circ} \mathrm{C}$ for $30 \mathrm{~s}$ and $72{ }^{\circ} \mathrm{C}$ for $2 \mathrm{~min}$. The 12th step ended with a cycle at $60{ }^{\circ} \mathrm{C}$ for $30 \mathrm{~min}$. A loading buffer $(1.5 \mu \mathrm{L})$ containing $1.25 \mu \mathrm{L}$ deionized formamide, $0.625 \mu \mathrm{L}$ loading solution and $0.125 \mu \mathrm{L}$ Rox Size Standard or $0.5 \mu \mathrm{L}$ of the selective amplified DNA, in a total volume of $2.0 \mu \mathrm{L}$, was then added. The tubes were heated to $95^{\circ} \mathrm{C}$ for $5 \mathrm{~min}$ and then rapidly placed on ice. A $1.0 \mu \mathrm{L}$ - volume of each sample was loaded on a 5\% Long Ranger denaturing gel made with $1 \mathrm{X}$ TBE (Tris - $0.089 \mathrm{M}$, boric acid $0.089 \mathrm{M}$, EDTA $-0.002 \mathrm{M}$ ) as running buffer and the gel was run in an ABI PRISM ${ }^{\mathrm{TM}} 377$ DNA Sequencer (PE Applied Biosystems) for $3 \mathrm{~h}$ at 2,500 V.

\section{Statistical Analysis}

The mating system was analyzed based on the mixed mating model of Ritland and Jain (1981) using the MLDT program of Ritland (1990). The following parameters were estimated: multilocus outcrossing rate $\left(\hat{t}_{m}\right)$, single-locus outcrossing rate $\left(\hat{t}_{s}\right)$, outcrossing rate between relatives $\left(\hat{t}_{m}-\hat{t}_{s}\right)$, ovule and pollen allele frequencies $(o$ and $p)$, and the inbreeding coefficient of maternal parent trees $\left(\hat{F}_{m}\right)$. The standard error of the reported estimates was calculated based on 300 bootstraps, where the sampling units were the plants within progenies for the individual outcrossing rate per maternal tree, and the families for the populational outcrossing rate.

The genetic divergence among families and coefficient of coancestry within families $(\hat{\theta})$ were obtained using the TFPGA program (Miller, 1997), with the allele frequencies being estimated by the method of Lynch and Milligan (1994). The estimate of $\hat{\theta}$ was used to calculate the correlations of paternity $\left(\hat{r}_{p}\right)$. Ritland (1989) showed that the coefficient of correlation within families can be estimated by

$$
\hat{r}_{x y}=0.25(1+\hat{F})\left[4 \hat{s}+\left(\hat{t}^{2}+\hat{t} \hat{r}_{s}\right)\left(1+\hat{r}_{p}\right)\right]
$$

where $\hat{F}$ is the inbreeding coefficient of parental population, $\hat{s}$ is the self-fertilization rate, and $\hat{r}_{s}$ is the correlation of outcrossing. As the coefficient of coancestry is half of the coefficient of correlation within families $\left(\hat{\theta}=\hat{r}_{x y} / 2\right)$, then

$$
\hat{\theta}=0.125(1+\hat{F})\left[4 \hat{s}+\left(\hat{t}^{2}+\hat{t} \hat{s}_{s}\right)\left(1+\hat{r}_{p}\right)\right]
$$

Still, since the species is predominantly dioecious, there is probably no variation in the individual outcrossing rate $\hat{r}_{s}$, which can be assumed to be zero. Assuming also $\hat{F}=0$, then

$$
\hat{\theta}=0.125\left[4 \hat{s}+\hat{t}^{2}\left(1+\hat{r}_{p}\right)\right]
$$

and $\hat{r}_{p}$ can be estimated per

$$
\hat{r}_{p}=\frac{\hat{\theta}-0.125\left(4 \hat{s}+\hat{t}^{2}\right)}{0.125 \hat{t}^{2}}
$$

\section{Results}

The three primer pairs used in the fAFLP analysis revealed a total of 137 polymorphic loci. Eleven loci close to intermediate frequency $(0.5)$ were selected for the mating system investigation. According to Ritland and Jain (1981), alleles with an intermediate or close to intermediate frequency are more appropriate for the estimation of multilocus outcrossing rates because they allow a better distinction between plants generated by outcrossing events and those obtained by self-fertilization.

The estimated genetic divergence between the pollen versus ovule allele frequencies was significant for the eight loci studied (Table 1), with a $5 \%$ probability being observed for locus 5 , while the other loci showed a significant difference at the $1 \%$ level. The heterogeneity in the allele 
Table 1 - Maximum likelihood estimates of pollen and ovule allele frequencies in the progeny of M. urundeuva.

\begin{tabular}{|c|c|c|c|c|c|c|c|}
\hline Locus & Allele & Pollen pool (SE) & Ovule pool (SE) & $n$ & $\hat{F}_{S T}$ & $\chi^{2}$ & Df \\
\hline \multirow[t]{2}{*}{1} & 1 & $0.629(0.046)$ & $0.413(0.088)$ & & & & \\
\hline & 2 & $0.371(0.046)$ & $0.587(0.088)$ & 270 & 0.047 & $25.24 * *$ & 1 \\
\hline \multirow[t]{2}{*}{2} & 1 & $0.581(0.042)$ & $0.591(0.048)$ & & & & \\
\hline & 2 & $0.419(0.042)$ & $0.409(0.048)$ & 270 & 0.000 & $0.06^{\mathrm{ns}}$ & 1 \\
\hline \multirow[t]{2}{*}{3} & 1 & $0.468(0.087)$ & $0.097(0.055)$ & & & & \\
\hline & 2 & $0.532(0.087)$ & $0.903(0.055)$ & 270 & 0.170 & $91.67 * *$ & 1 \\
\hline \multirow[t]{2}{*}{4} & 1 & $0.500(0.007)$ & $0.040(0.007)$ & & & & \\
\hline & 2 & $0.500(0.007)$ & $0.960(0.007)$ & 270 & 0.268 & $144.93^{* *}$ & 1 \\
\hline \multirow[t]{2}{*}{5} & 1 & $0.597(0.049)$ & $0.511(0.051)$ & & & & \\
\hline & 2 & $0.403(0.049)$ & $0.489(0.051)$ & 270 & 0.007 & $4.04 *$ & 1 \\
\hline \multirow[t]{2}{*}{6} & 1 & $0.435(0.031)$ & $0.031(0.046)$ & & & & \\
\hline & 2 & $0.565(0.031)$ & $0.969(0.046)$ & 270 & 0.228 & $123.29 * *$ & 1 \\
\hline \multirow[t]{2}{*}{7} & 1 & $0.419(0.065)$ & $0.166(0.031)$ & & & & \\
\hline & 2 & $0.581(0.065)$ & $0.834(0.031)$ & 270 & 0.077 & $41.76^{* *}$ & 1 \\
\hline \multirow[t]{2}{*}{8} & 1 & $0.694(0.038)$ & $0.655(0.054)$ & & & & \\
\hline & 2 & $0.306(0.038)$ & $0.345(0.054)$ & 270 & 0.002 & $0.94^{\mathrm{ns}}$ & 1 \\
\hline \multirow[t]{2}{*}{9} & 1 & $0.613(0.047)$ & $0.611(0.068)$ & & & & \\
\hline & 2 & $0.387(0.047)$ & $0.389(0.068)$ & 270 & 0.000 & $0.00^{\mathrm{ns}}$ & 1 \\
\hline \multirow[t]{2}{*}{10} & 1 & $0.548(0.063)$ & $0.443(0.061)$ & & & & \\
\hline & 2 & $0.452(0.063)$ & $0.557(0.061)$ & 270 & 0.011 & $5.95 * *$ & 1 \\
\hline \multirow[t]{2}{*}{11} & 1 & $0.468(0.029)$ & $0.041(0.030)$ & & & & \\
\hline & 2 & $0.532(0.029)$ & $0.959(0.030)$ & 270 & 0.024 & $64.87^{* *}$ & 1 \\
\hline
\end{tabular}

${ }^{* *}: \mathrm{p} \leq 0.01 .^{*}: \mathrm{p} \leq 0.05$. Genetic divergence $\left(\hat{F}_{S T}\right)$ and chi-square statistics $\left(\chi^{2}\right)$ to test the differences between pollen vs. ovule allele frequencies.

frequencies of pollen and ovules indicated deviations from random outcrossing, probably correlated outcrossing and/or biparental inbreeding.

The estimate for the multilocus outcrossing rate $\left(\hat{t}_{m}\right)$ was high $(0.940 \pm 0.086)$ and not significantly different from 1.0 , as determined by the standard error, indicating that M. urundeuva is a species of outcrossing (Table 2). The single-locus outcrossing rate $\left(\hat{t}_{s}=1.088 \pm 0.109\right)$ was also equal to 1.0 , reinforcing that it is a species of outcrossing. The difference between the multilocus and single-locus outcrossing rates was negative and significantly different from zero $(-0.149 \pm 0.040)$, suggesting an absence of biparental inbreeding. Individual outcrossing estimates showed that families 3,17 and 27 did not converge on any reliable value from the biological stand point (value of 2.0; Ritland, 1990); it was therefore not possible to determine the magnitude of their outcrossing rate. Thus these families were excluded from the analyses of the populational outcrossing rate. For the other families, the individual multilocus outcrossing rate $(\hat{t})$ ranged from 0.56 (family $26)$ to 1.19 (family 14). But only the individual outcrossing of families 4, 16, 25, 26 and 30 were significantly different from $\hat{t}>1.0$. Values of 1.0 are biologically interpreted as being equal to one.
The maternal trees fixation index $\left(\hat{F}_{m}\right)$ was negative $(-0.300)$ and significantly different from zero, indicating excess heterozygotes in the maternal trees. Genetic divergence among progenies or coancestry within families $\hat{\theta}=0.185)$ was significantly different from zero and higher than that expected for half-sib progenies $(0.125)$. The correlation of paternity $\left(\hat{r}_{p}\right)$ was estimated from $\hat{\theta}$. The $\hat{r}_{p}$ value was high for the population (0.403), indicating that progenies have a high proportion of full-sibs.

\section{Discussion}

M. urundeuva is considered to be a dioecious species by some researchers (Santin and Leitão Filho, 1991) and as monoecious by others (Nogueira et al., 1982). In progeny tests, both individuals types are found, but the great majority of trees found are dioecious (Moraes and Sebbenn, 2003). In accordance with this statement, the estimate of the multilocus outcrossing rate $\left(\hat{t}_{m}\right)$ for the M. urundeuva population was high and not significantly different from 1.0 $(0.940 \pm 0.086)$, confirming that this species produces offspring predominantly by outcrossing. Moraes and Sebbenn (2003), analyzing the mating system in two populations of M. urundeuva using six polymorphic allozyme loci, ob- 
Table 2 - Estimate of the individual multilocus outcrossing rate $(\hat{t})$ and mating system parameters of an M. urundeuva population.

\begin{tabular}{|c|c|c|c|c|c|}
\hline Progeny & $n$ & $\hat{t}$ & Progeny & $n$ & $\hat{t}$ \\
\hline 1 & 9 & $0.81(0.36)$ & 16 & 9 & $0.58(0.20)$ \\
\hline 2 & 9 & $0.78(0.41)$ & 17 & 9 & $\mathrm{nc}$ \\
\hline 3 & 9 & $\mathrm{nc}$ & 18 & 9 & $0.71(0.47)$ \\
\hline 4 & 9 & $0.57(0.21)$ & 19 & 9 & $0.77(0.43)$ \\
\hline 5 & 9 & $0.78(0.41)$ & 20 & 9 & $0.75(0.46)$ \\
\hline 6 & 9 & $0.98(0.61)$ & 21 & 9 & $0.82(0.64)$ \\
\hline 7 & 9 & $1.06(0.77)$ & 22 & 9 & $0.75(0.46)$ \\
\hline 8 & 9 & $0.83(0.27)$ & 23 & 9 & $0.66(0.44)$ \\
\hline 9 & 9 & $0.90(0.67)$ & 24 & 9 & $0.74(0.41)$ \\
\hline 10 & 9 & $0.80(0.49)$ & 25 & 9 & $0.67(0.30)$ \\
\hline 11 & 9 & $0.84(0.51)$ & 26 & 9 & $0.56(0.20)$ \\
\hline 12 & 9 & $0.82(0.62)$ & 27 & 9 & $\mathrm{nc}$ \\
\hline 13 & 9 & $0.88(0.31)$ & 28 & 9 & $0.89(0.56)$ \\
\hline 14 & 9 & $1.19(0.61)$ & 29 & 9 & $0.89(0.57)$ \\
\hline 15 & 9 & $0.86(0.37)$ & 30 & 9 & $0.70(0.29)$ \\
\hline \multicolumn{4}{|c|}{ Fixation index of the maternal trees } & \multicolumn{2}{|r|}{$-0.300(0.000)$} \\
\hline \multicolumn{4}{|c|}{ Coefficient of relatedness among progenies } & \multicolumn{2}{|r|}{$0.185[0.139$ to 0.231$]$} \\
\hline \multicolumn{4}{|c|}{ Single-locus outcrossing rate } & \multicolumn{2}{|r|}{$1.088(0.109)$} \\
\hline \multicolumn{4}{|c|}{ Multilocus outcrossing rate } & \multicolumn{2}{|r|}{$0.940(0.086)$} \\
\hline \multicolumn{4}{|c|}{ Biparental inbreeding } & \multicolumn{2}{|r|}{$-0.149(0.040)$} \\
\hline \multicolumn{4}{|c|}{ Correlation of paternity } & \multicolumn{2}{|r|}{0.403} \\
\hline
\end{tabular}

nc: Estimate of the individual non-converged outcrossing rate.

( ): Standard error.

[ ]: 95\% confidence interval.

tained a high multilocus outcrossing rate, but with significant differences among them, with values of $0.899 \pm 0.041$ and $0.951 \pm 0.027$, respectively. Some of the trees in the Paulo de Faria population are probably monoecious, which would explain the levels of self-fertilization. The outcrossing rates obtained in the present study also emphasize that this specie is allogamous.

The single-locus estimate $\left(\hat{t}_{s}\right)$ was $1.0(1.088 \pm$ $0.109)$, confirming that the species reproduces itself by outcrossing. The difference in the multilocus and single-locus outcrossing rates $\left(\hat{t}_{m}-\hat{t}_{s}\right)$ was negative, suggesting an absence of biparental inbreeding (Ritland and Jain, 1981). Moraes and Sebbenn (2003) studying the same population based on allozyme loci, observed a rate of $4.8 \%$ for biparental inbreeding. This difference in the outcrossing rate among related individuals observed in the same population might be attributed to various factors such as variations in the mating system during the different reproductive events, sampling errors and to the fact that the estimates were calculated based on data obtained by different genetic markers.

The magnitude of the estimated mean of coancestry within families $(\hat{\theta}=0.185)$ was higher than that expected for half-sib progenies (0.125), raising the hypothesis of correlated outcrossing and/or biparental inbreeding in the population (Table 2). The $\hat{\theta}$ coefficient assumes values of 0.125 in half-sib progenies, of 0.25 in full-sib progenies and of 0.5 in selfed sibs. The results of the multilocus outcrossing rate estimate showed that the species is perfectly allogamous and differences between multilocus and single-locus also suggest the absence of biparental inbreeding. Thus the progenies may be considered a mixture of full-sibs and half-sibs. In mixed half-sibs and full-sibs progenies, $\hat{\theta}$ values become intermediate, between 0.125 and 0.25 , with the tendency towards one or the other limit being determined by the type of progeny that is present in a higher proportion. Thus the cause of the high coancestry is probably due to the correlated mating.

The indirect estimate of correlation of paternity within families was high $\left(\hat{r}_{p}=0.403\right)$ showing that about $38 \%\left(\hat{t}_{m} \hat{r}_{p}\right)$ of the progenies are full-sibs and $62 \%$ half-sibs $\left[\hat{t}_{m}\left(1-\hat{r}_{p}\right)\right]$. The possible explanations for the correlated outcrossing in the population include flowering asynchrony, a small number of flowers on the trees, a small number of potentially pollinating trees, and the lack of 
movement of pollinating insects among neighboring trees. All these explanations are plausible in M. urundeuva, however, it is difficult to determine the true causes for correlated outcrossing with accuracy. For this determination it would have been necessary to monitor, in detail, the reproductive events that originated the seeds herein analyzed. Since we did not perform this analysis, the most likely hypothesis that would account for this situations is believed to be associated with the flowering asynchrony, together with the behavior of different pollinators visiting adjacent trees, due to the fact that the species shows a wide and variable flowering period from June to August within the State of São Paulo (Carvalho, 1994). Since the flowering period is often marked by an initial phase during which a few of the trees present flowers, followed by a period of peak flowering and a final phase of scarce flowering, the initial and final asynchrony would favor correlated outcrossing. The hypothesis of a small number of pollinating trees can be ruled out because, although having been exploited in the past, the population shows a high density in the studied area ( $>5$ individuals per hectare).

The high proportion of correlated outcrossing implies an increased probability of the establishment of full-sib individuals in the population, a fact that might explain the biparental inbreeding observed by Moraes and Sebbenn (2003). The authors also found a high correlation of paternity in the population $\left(\hat{r}_{p}=0.389\right)$. Correlation of paternity also was detected for some other tropical tree species such as Eucalyptus marginata ( $\hat{r}_{p}$ variation of 0.530 to 0.920; Millar et al. 2000), Enterolobium cyclocarpum $\left(\hat{r}_{p}\right.$ variation of 0.174 to 0.462; Rocha and Aguilar 2001), Cariniana legalis $\left(\hat{r}_{p}\right.$ variation of 0.219 to 0.324 ; Sebbenn et al. 2000) and Eucalyptus camaldulensis $\left(\hat{r}_{p}\right.$ variation of 0.079 to 0.365; Butcher and Williams 2002).

The mating system plays a fundamental role in the amplification and recombination of the genetic variability of a population of a species. Thus the deviations from random outcrossing observed in M. urundeuva have important implications for genetic conservation and genetic improvement. In ex situ conservation activities, the deviations from random outcrossing imply the need for sample size maintenance to be larger than those predicted for populations in Hardy-Weinberg equilibrium without inbreeding and relatedness in the parental generation, due the deviations from random outcrossing that reduce the effective population number. Based on the coancestry within progenies, it was possible to determine the variance effective population size $\left(N_{e}\right)$. Cockerham (1969) defined the variance effective population size of a single family based on coancestry $(\hat{\theta})$ and inbreeding in the families $(\hat{F})$, as follows,

$$
\hat{N}_{e}=\frac{0.5}{\hat{\theta}\left(\frac{n-1}{n}\right)+\frac{1+\hat{F}}{2 n}}
$$

where $n$ is the total number of progeny plants (sum of all progeny plants). Substituting parameters $\hat{\theta}$ (Table 2 ) and assuming $\hat{F}=0$, Cockerham's (1969) expression provides a $N_{e}$ of a simple family of 2.671. If the population is larger and perfectly panmictic, the $N_{e}$ is 4 . Thus the variance of effective size estimated was $33.2 \%$ lower than that expected for populations with random outcrossing. This implies that for conservation of genetic variability a larger sample size than required for a panmictic population needs to be maintained.

For genetic improvement, deviations from random outcropping require the adoption of more elaborate genetic-statistical models than those routinely used in quantitative genetic studies. Cockerham and Weir (1984) and Ritland (1989) presented a genetic model specific for populations with deviations from random outcrossing.

\section{Acknowledgment}

The authors would like to thank FAPESP for supporting this research (Project No. 99/08426-8).

\section{References}

Butcher PA and Williams ER (2002) Variation in outcrossing rates and growth in Eucalyptus camaldulensis from the Petford Region, Queensland; Evidence of outbreeding depression. Silvae Genetica 51:65-72.

Carvalho PER (1994) Espécies Florestais Brasileiras: Recomendações Silviculturais, Potencialidades e Uso de Madeira. EMBRAPA, Brasília, 640 pp.

Cockerham CC (1969) Variance of gene frequencies. Evolution 23:72-84

Cockerham CC and Weir BS (1984) Covariances of relatives stemming a population undergoing mixed self and random mating. Biometrics 40:157-164.

Corrêa MP (1926) Dicionário das plantas úteis do Brasil e das exóticas cultivadas. Rio de Janeiro: Imprensa Nacional pp 443-444.

Doyle JJ and Doyle JL (1987) Isolation of plant DNA from fresh tissue. Focus 12:13-15.

Ferreira ME and Grattapaglia D (1998) Introdução ao uso de marcadores moleculares em análise genética. EMBRAPA CENARGEN, Brasília, 220 pp.

Gaiotto FA, Bramucci M and Grattapaglia D (1997) Estimation of outcrossing rate in a breeding populations of Eucalyptus urophylla with dominant RAPD and AFLP markers. Anais... IUFRO - Conference on Silviculture and Improvement of Eucalyptus, Salvador, 2:53-57.

Hamrick JL (1983) The distribution of genetic variation within and among natural plant populations. In: Schone-Wald-Cox CM, Chambers SH, MacByde B and Thomas L (eds.) Genetics and Conservation. Benjamin Cummings Publishing Company, Menlo Park, pp 335-348.

Hamrick JL and Loveless MD (1986) The influence of seed dispersal mechanisms on the genetic structure of plant populations. In: Estrada A and Fleming TH (eds) Frugivores and Seed Dispersa. Junk Publishers, 392 pp.

Hamrick JL and Godt MJW (1989) Allozyme diversity in plant species. In: Brown AHD, Clegg MT, Kahler AL and Weir 
BS (eds) Plant Population Genetics, Breeding and Genetic Resources. Sinauer Associates, Sunderland, MA, pp 43-63.

Loveless MD, Hamrick JL and Foster RB (1998) Population structure and mating system in Tachigali versicolor, a monocarpic neotropical tree. Heredity 81:134-143.

Lorenzi H (1992) Árvores Brasileiras: Manual de Identificação e Cultivo de Plantas Arbóreas Nativas do Brasil. Ed. Plantarun, Nova Odessa, 302 pp.

Lynch M and Milligan BG (1994) Analysis of population genetic structure with RAPD markers. Molecular Ecology 3:91-99.

Millar MA, Byrne M, Coates DJ, Stukely MJC and McCom JA (2000) Mating system studies in jarrah, Eucalyptus marginata (Myrtaceae). Aust J Bot 48:475-479.

Miller MP (1997) TFPGA - Analytical Software Page. Available from http://bioweb.usu.edu/mpmbio/tfpga.htm.

Moraes MLT and Sebbenn AM (2003) Mating system in natural populations of tropical tree, Myracrodruon urundeuva F.F. \& M.F. Allemão from Brazil. Forest Genetics, Sloven, 21 pp (submitted).

Murawski DA (1995) Reproductive biology and genetics of tropical trees from canopy perspective. In: Lowman MD and Nadkarni NM (eds) Forest Canopies. Academic Press, pp 457-493.

Murawski DA, Hamrick JL, Hubbell SP and Foster RB (1990) Mating system of two Bombacaceous trees of a neotropical moist forest. Oecologia 82:501-506.

Nogueira JCB, Siqueira ACMF, Moraes E, Coelho LCC, Mariano G, Kageyama PY, Zanatta AC and Figliolia MB (1982) Conservação genética de essências nativas através de ensaios de procedências. Anais... Congresso Nacional Sobre Essências Nativas, Campos do Jordão, Silvicultura em São Paulo 6A, 2, 957-969.
Record SJ and Hess RW (1949) Timbers of New World. $4^{\text {nd }}$ ed. Yale University Press, New Haven, 640 pp.

Ritland K (1989) Correlated matings in the partial selfer Mimulus guttatus. Evolution 43:848-859.

Ritland K (1990) Series of FORTRAN computer programs for estimating plant-mating systems. Journal of Heredity 81:235237.

Ritland K and Jain S (1981) A model for the estimation of outcrossing rate and gene frequencies using independent loci. Heredity 47:35-52.

Rizzini CT (1971) Árvores e madeiras úteis do Brasil: Manual de dendrologia brasileira. Edgard Blücher, São Paulo, 294 pp.

Rocha OJR and Aguilar G (2001) Variation in the breeding behavior of the dry forest tree Enterolobium cyclocarpum (Guanacaste) in Costa Rica. Amer J Bot 89:1600-1606.

Sambrook J, Fritsch EF and Maniatis T (1989) Molecular cloning: A laboratory manual. $2^{\text {nd }} \mathrm{ed}$. Cold spring Harbor Laboratory, Cold Spring Harbor, New York.

Santin DA and Leitão Filho HF (1991) Restabelecimento e revisão taxonômica do gênero Myracrodruon Freire Alemão (Anacardiaceae). Rev Bras de Bot 14:133-145.

Scott KD, Ablett EM, Lee LS and Henry RJ (2000) AFLP markers distinguish an early mutant of flame seedless grape. Euphytica 113:245-249.

Sebbenn AM, Kageyama PY, Siqueira ACMF and Zanatto ACE (2000) Taxa de cruzamento em populações de Cariniana legalis (Mart.) O. Ktze.: Implicações para a conservação e o melhoramento genético. Scientia Forestalis 58:25-40.

Vos P, Hogers R, Bleeker M, Reijans M, Van De Lee T, Hornes M, Frijters A, Pot J, Peleman J, Kuiper M, and Zabeau, M (1995) AFLP: A new technique for DNA fingerprinting. Nucleic Acids Res. 23:4407-4414.

Associate Editor: José Francisco Ferraz de Toledo 